\title{
Health Hazardous of Specific Absorption Rate (SAR) of Mobile Phone Tower Waves
}

\author{
Mushtaq Ahmed Bhat ${ }^{1}$ \\ Department of Physics Graphic Era University Dehradun (U. K)
}

\begin{abstract}
The physiological mechanism of mobile phone radiation related health effect is not well known. Mobile phone and their tower radiations affect human skin and blood. Those People who often talk on mobile phone handset or living near their tower have higher interaction with radiation. In this paper penetration of high frequency electromagnetic waves emitted from mobile phone tower into human skin and blood tissues was studied. The effect of specific absorption rate (SAR) was calculated at frequencies 800, 900, 1800 and $2450 \mathrm{MHz}$ and effective radiated power from the mobile phone tower is taken as 20 Watts.
\end{abstract}

Keywords: Mobile Phone Tower, Electromagnetic Waves, Skin And Blood Tissues, Specific Absorption Rate.

\section{INTRODUCTION}

The measured rate at which energy is absorbed by the human body when exposed to a radio frequency (RF) electromagnetic field (EMF) is specific absorption rate (SAR). It is also defined as the power absorbed by the tissue per unit mass and is measure in watts per kilogram $(\mathrm{W} / \mathrm{kg})$. SAR is usually averaged either over the whole body or over a body tissue. The SAR is determined at the highest certified power level, the actual SAR level of the device while operating can be well below the maximum value. If we measure the specific absorption rate then mobile phone handset should be placed at the head in a talk position. Specific absorption rate value is then measured at the highest location of absorption rate in the entire head, which the mobile phone handset is often as close to their antenna as possible [1]. SAR values increase with the increase of conductivities of human body tissues and decreases with the increase of relative permittivity of human body tissues. Specific absorption rate describes the possible biological effects of RF fields. The high energy radio frequency field exposure causes thermal effects in biological tissues and generates high SAR values. This is called non-thermal effect. The effect of dielectric values of human body on SAR is frequency dependent and orientation of human body [2]. The maximum increase in temperature of human head tissue is due to specific absorption rate (SAR).

A number of countries have their own regulations for occupational exposure and general public exposure to radiofrequency electromagnetic radiation. For instance, the SAR limits adopted by Japan and South Korea are based on the ICNIRP limits [3] whereas those adopted by the USA and Canada are based on the ANSI/IEEE limits [4]. For USA, Australia and some other countries, certain devices operating within close proximity to human body such as mobile phone handsets and satellite phone handsets are required to have mandatory SAR compliance testing or evaluation. Although an international standard for SAR testing or evaluation is not yet available, the regionally recognized standards such as ANSI/IEEE 19925 and EN 50361 are used by some overseas countries [2]. Specific absorption rate values are dependent upon the size of the averaging volume. Comparisons between different measurements cannot be made without information averaging volume used. There is confusion and misunderstanding about the specific absorption rate values for mobile phones and other wireless system. In case of mobile phone, the rate of radiofrequency energy absorption by the body can be measured by specific absorption rate. SAR gives meaning for measuring the radiofrequency exposure of mobile phone waves within the safety guidelines set by the Federal Communications Commission [5].Many people consider that using mobile phone handset with a lower value of specific absorption rate is safer than the mobile phone handset having high specific absorption value. Actually specific absorption value is an important tool in checking the maximum possible exposure to radiofrequency energy from a particular model of mobile phone handset. A single value of specific absorption rate does not give complete information about the amount of radiofrequency exposure [6].

\section{Calculations of Penetrated Electric Field and SPecific Absorption Rate (SAR)}

If mobile phone tower is consider as point source, the radiation is emitted around are as spherical wave front of radius $r$. Let $\mathrm{E}_{0}$ be the incident electric field and $\mathrm{P}$ is power of radiation around the transmission tower, then

${ }^{1}$ Corresponding Author: dmbhat5979@gmail.com 
Radiating power per unit area is represented by.

$$
\begin{array}{r}
\frac{P}{4 \pi r^{2}}=\frac{1}{2} \varepsilon_{0} E_{0}^{2} c \\
E_{0}=\left[\frac{P}{2 \pi r^{2} \varepsilon_{0} c}\right]^{\frac{1}{2}}=\frac{7.746 \sqrt{P}}{r} \ldots \ldots \ldots \ldots \ldots
\end{array}
$$

Where $\varepsilon_{0}$ is the permittivity of free space and $c$ the velocity of radiation

If the mobile phone tower of power radiates $20 \mathrm{~W}$ power, the electric field can be calculated by

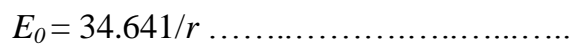

Penetrated electric field inside the biological tissues can be calculated by the equation

$$
\mathrm{E}_{\mathrm{z}}=\mathrm{E}_{\mathrm{o}} \mathrm{e}^{(-\mathrm{z} / \mathrm{\delta})}
$$

Where $E_{z}$ is the field inside the depth $\mathrm{z}, \mathrm{E}_{0}$ is the magnitude of field inside the boundary and $\delta$ is skin depth. For biological materials skin depth is given by

$$
\delta=\frac{1}{\omega q} \cdots \cdots \cdots \cdots \cdots \cdots \cdots
$$

Where $\sigma$ conductivity of biological material and $\omega$ is is angular frequency of radiation.

\section{Standard values}

> At $2450 \mathrm{MHz}, \sigma=1.5919 \mathrm{~W} \mathrm{~K}^{-1} \mathrm{~m}^{-1}$, skin depth $\delta=28.808 \mathrm{~mm}$,

$>$ At $1800 \mathrm{MHz}, \sigma=1.232 \mathrm{~W} \mathrm{~K}^{-1} \mathrm{~m}^{-1}$, skin depth $\delta=28.808 \mathrm{~mm}$,

$>$ At $900 \mathrm{MHz}, \sigma=0.84465 \mathrm{~W} \mathrm{~K}^{-1} \mathrm{~m}^{-1}$, of skin depth $\delta=43.352 \mathrm{~mm}$

$>$ At $800 \mathrm{MHz}, \sigma=0.80864 \mathrm{~W} \mathrm{~K}^{-1} \mathrm{~m}^{-1}$, skin depth $\delta=45.59 \mathrm{~mm}$,

> $\mathrm{z}=0.1 \mathrm{~mm}, 0.2 \mathrm{~mm}, 0.3 \mathrm{~mm}, 0.4 \mathrm{~mm}$ and $0.5 \mathrm{~mm}$

The value of density $\rho$ for blood $=1060 \mathrm{~kg} \mathrm{~m}^{-3}$, for skin $=1070 \mathrm{~kg} \mathrm{~m}^{-3}$

For frequency of EMW of $10 \mathrm{MHz}-10 \mathrm{GHz}$ its safe limit $=0.4 \mathrm{~W} / \mathrm{kg}$ [3].

Reference levels for general public exposure to time-varying electric fields with frequency (f) [3].

For frequency $\mathrm{f}=2450 \mathrm{MHz}, \mathrm{E}=68.059 \mathrm{~V} / \mathrm{m}$

For frequency $\mathrm{f}=1800 \mathrm{MHz}, \mathrm{E}=58.33 \mathrm{~V} / \mathrm{m}$

For frequency $\mathrm{f}=900 \mathrm{MHz}, \quad \mathrm{E}=40.35 \mathrm{~V} / \mathrm{m}$

For frequency $\mathrm{f}=800 \mathrm{MHz}, \quad \mathrm{E}=38.89 \mathrm{~V} / \mathrm{m}$

By Pointing vector theorem SAR can be define as

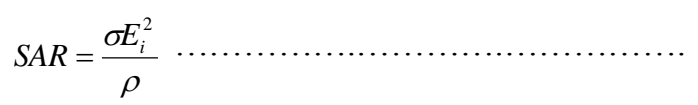

Where $\mathrm{Ei}$ is the field inside that material, $\sigma$ is the conductivity of the material.

This relation shows that the rate of electromagnetic energy is converted into heat energy through well interaction mechanisms.

For frequency of EMW of $10 \mathrm{MHz}-10 \mathrm{GHz}$ its safe limit $=0.4 \mathrm{~W} / \mathrm{kg}$ [3]

\section{RESULT AND DISCUSSION}

For the calculation of SAR inside the body, the distance from mobile phone tower radiation are taken from $1 \mathrm{~m}$ to $50 \mathrm{~m}$ for this study of skin, blood, tissues at four frequencies namely $800,900,1800$ and $2450 \mathrm{MHz}$ and power of radiation for mobile phone tower is taken $20 \mathrm{~W}$. 
American Research Journal of Physics, Volume 1, Issue 2, 2016

ISSN 2380-5714

Table1. SAR inside the skin due to the electromagnetic wave of $800 \mathrm{MHz}$ frequency of mobile phone tower at depths $0.1 \mathrm{~mm}$ to $0.5 \mathrm{~mm}$ inside the body from $1 \mathrm{~m}$ to $50 \mathrm{~m}$ from the mobile phone tower.

\begin{tabular}{|c|c|c|c|c|c|}
\hline Distance from tower in (m) & \multicolumn{5}{|c|}{ SAR for skin at f=800 MHz } \\
\cline { 2 - 5 } & $\mathbf{0 . 1}$ & $\mathbf{0 . 2}$ & $\mathbf{0 . 3}$ & $\mathbf{0 . 4}$ & $\mathbf{0 . 5}$ \\
\hline 1 & $\mathbf{0 . 9 0 1 5 0 8}$ & $\mathbf{0 . 8 9 7 5 6 2}$ & $\mathbf{0 . 8 9 3 6 3 3}$ & $\mathbf{0 . 8 8 9 7 2 2}$ & $\mathbf{0 . 8 8 5 8 2 7}$ \\
\hline 5 & 0.03606 & 0.035902 & 0.035745 & 0.035589 & 0.035433 \\
\hline 10 & 0.009015 & 0.008976 & 0.008936 & 0.008897 & 0.008858 \\
\hline 15 & 0.004007 & 0.003989 & 0.003972 & 0.003954 & 0.003937 \\
\hline 20 & 0.002254 & 0.002244 & 0.002234 & 0.002224 & 0.002215 \\
\hline 25 & 0.001442 & 0.001436 & 0.00143 & 0.001424 & 0.001417 \\
\hline 30 & 0.001002 & 0.000997 & 0.000993 & 0.000989 & 0.000984 \\
\hline 35 & 0.000736 & 0.000733 & 0.000729 & 0.000726 & 0.000723 \\
\hline 40 & 0.000563 & 0.000561 & 0.000558 & 0.000556 & 0.000554 \\
\hline 45 & 0.000445 & 0.000443 & 0.000441 & 0.000439 & 0.000437 \\
\hline 50 & 0.000361 & 0.000359 & 0.000357 & 0.000356 & 0.000354 \\
\hline
\end{tabular}

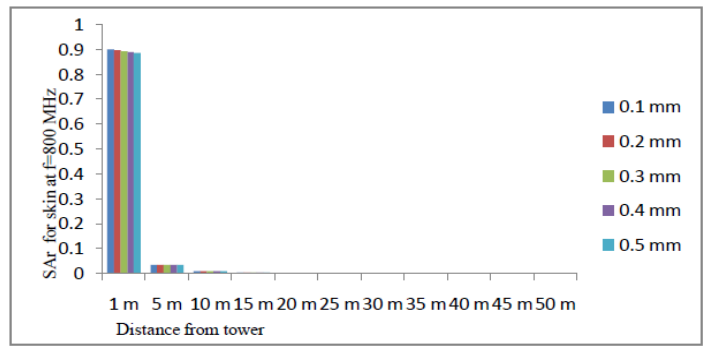

Fig1. The variation of $S A R$ in $W / K g$ for skin (tower) at frequency $800 \mathrm{MHz}$.

Table2. SAR inside the skin due to the electromagnetic wave (900 MHz) of mobile phone tower at depths $0.1 \mathrm{~mm}$ to $0.5 \mathrm{~mm}$ inside the body from $1 \mathrm{~m}$ to $50 \mathrm{~m}$ from the mobile phone tower.

\begin{tabular}{|c|c|c|c|c|c|}
\hline \multirow{2}{*}{$\begin{array}{c}\text { Distance from } \\
\text { tower in (m) }\end{array}$} & \multicolumn{5}{|c|}{ SAR for skin at f=900 MHz } \\
\cline { 2 - 6 } & $\mathbf{0 . 1}$ & $\mathbf{0 . 2}$ & $\mathbf{0 . 3}$ & $\mathbf{0 . 4}$ & $\mathbf{0 . 5}$ \\
\hline 1 & $\mathbf{0 . 9 4 1 4 4 1}$ & $\mathbf{0 . 9 3 7 1 0 8}$ & $\mathbf{0 . 9 3 2 7 9 4}$ & $\mathbf{0 . 9 2 8 5 0 1}$ & $\mathbf{0 . 9 2 4 2 2 7}$ \\
\hline 5 & 0.037658 & 0.037484 & 0.037312 & 0.03714 & 0.036969 \\
\hline 10 & 0.009414 & 0.009371 & 0.009328 & 0.009285 & 0.009242 \\
\hline 15 & 0.004184 & 0.004165 & 0.004146 & 0.004127 & 0.004108 \\
\hline 20 & 0.002354 & 0.002343 & 0.002332 & 0.002321 & 0.002311 \\
\hline 25 & 0.001506 & 0.001499 & 0.001492 & 0.001486 & 0.001479 \\
\hline 30 & 0.001046 & 0.001041 & 0.001036 & 0.001032 & 0.001027 \\
\hline 35 & 0.000768 & 0.000765 & 0.000761 & 0.000758 & 0.000754 \\
\hline 40 & 0.000588 & 0.000586 & 0.000583 & 0.00058 & 0.000578 \\
\hline 45 & 0.000465 & 0.000463 & 0.000461 & 0.000459 & 0.000456 \\
\hline 50 & 0.000376 & 0.000375 & 0.000373 & 0.000371 & 0.00037 \\
\hline
\end{tabular}

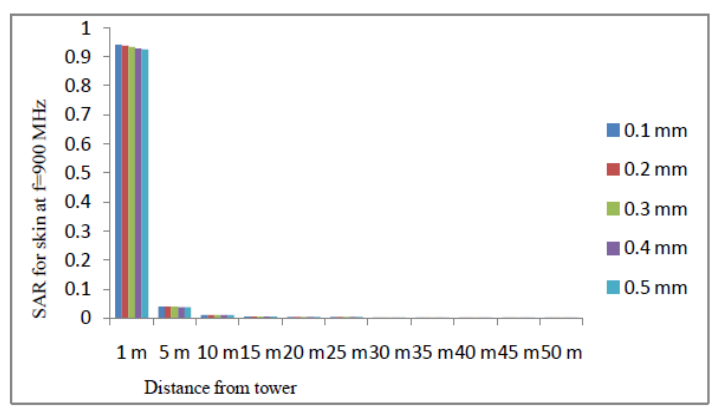

Fig2. The variation of SAR in $\mathrm{W} / \mathrm{Kg}$ for skin at frequency $900 \mathrm{MHz}$ 
American Research Journal of Physics, Volume 1, Issue 2, 2016

ISSN 2380-5714

Table3. SAR inside the skin due to the electromagnetic wave (1800 MHz) of mobile phone tower at depths $0.1 \mathrm{~mm}$ to $0.5 \mathrm{~mm}$ inside the body from $1 \mathrm{~m}$ to $50 \mathrm{~m}$ from the mobile phone tower.

\begin{tabular}{|c|c|c|c|c|c|}
\hline \multirow{2}{*}{ Distance from tower in (m) } & \multicolumn{5}{|c|}{ SAR for skin at f=1800 MHz } \\
\cline { 2 - 5 } & $\mathbf{0 . 1}$ & $\mathbf{0 . 2}$ & $\mathbf{0 . 3}$ & $\mathbf{0 . 4}$ & $\mathbf{0 . 5}$ \\
\hline 1 & $\mathbf{1 . 3 6 9 9 8 4}$ & $\mathbf{1 . 3 6 0 5 0 6}$ & $\mathbf{1 . 3 5 1 0 9 3}$ & $\mathbf{1 . 3 4 1 7 4 5}$ & $\mathbf{1 . 3 3 2 4 6 3}$ \\
\hline 5 & 0.054799 & 0.05442 & 0.054044 & 0.05367 & 0.053299 \\
\hline 10 & 0.0137 & 0.013605 & 0.013511 & 0.013417 & 0.013325 \\
\hline 15 & 0.006089 & 0.006047 & 0.006005 & 0.005963 & 0.005922 \\
\hline 20 & 0.003425 & 0.003401 & 0.003378 & 0.003354 & 0.003331 \\
\hline 25 & 0.002192 & 0.002177 & 0.002162 & 0.002147 & 0.002132 \\
\hline 30 & 0.001522 & 0.001512 & 0.001501 & 0.001491 & 0.001481 \\
\hline 35 & 0.001118 & 0.00111 & 0.001103 & 0.001095 & 0.001088 \\
\hline 40 & 0.000856 & 0.00085 & 0.000844 & 0.000838 & 0.000833 \\
\hline 45 & 0.000677 & 0.000672 & 0.000667 & 0.000663 & 0.000658 \\
\hline 50 & 0.000548 & 0.000544 & 0.00054 & 0.000537 & 0.000533 \\
\hline
\end{tabular}

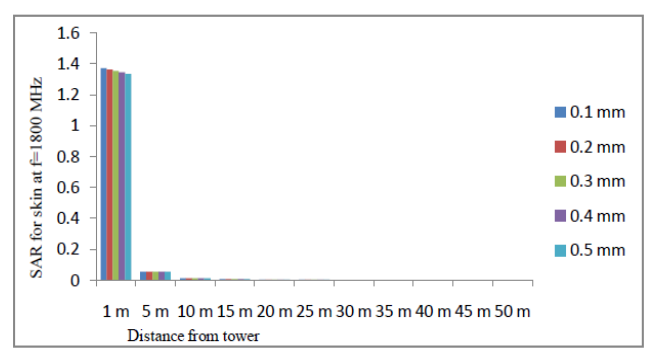

Fig3. The variation of SAR in $\mathrm{W} / \mathrm{Kg}$ for skin at frequency $1800 \mathrm{MHz}$.

Table4. SAR inside the skin due to the electromagnetic wave $(2450 \mathrm{MHz})$ of mobile phone tower at depths $0.1 \mathrm{~mm}$ to $0.5 \mathrm{~mm}$ inside the body from $1 \mathrm{~m}$ to $50 \mathrm{~m}$ from the mobile phone tower.

\begin{tabular}{|c|c|c|c|c|c|}
\hline \multirow{2}{*}{$\begin{array}{c}\text { Distance from } \\
\text { tower in (m) }\end{array}$} & \multicolumn{5}{|c|}{ SAR for skin at f=2450 MHz } \\
\cline { 2 - 6 } & $\mathbf{0 . 1}$ & $\mathbf{0 . 2}$ & $\mathbf{0 . 3}$ & $\mathbf{0 . 4}$ & $\mathbf{0 . 5}$ \\
\hline 1 & $\mathbf{1 . 7 6 6 4 1 5}$ & $\mathbf{1 . 7 5 0 4 5}$ & $\mathbf{1 . 7 3 4 6 3}$ & $\mathbf{1 . 7 1 8 9 5 2}$ & $\mathbf{1 . 7 0 3 4 1 7}$ \\
\hline 5 & 0.070657 & 0.070018 & 0.069385 & 0.068758 & 0.068137 \\
\hline 10 & 0.017664 & 0.017505 & 0.017346 & 0.01719 & 0.017034 \\
\hline 15 & 0.007851 & 0.00778 & 0.007709 & 0.00764 & 0.007571 \\
\hline 20 & 0.004416 & 0.004376 & 0.004337 & 0.004297 & 0.004259 \\
\hline 25 & 0.002826 & 0.002801 & 0.002775 & 0.00275 & 0.002725 \\
\hline 30 & 0.001963 & 0.001945 & 0.001927 & 0.00191 & 0.001893 \\
\hline 35 & 0.001442 & 0.001429 & 0.001416 & 0.001403 & 0.00139 \\
\hline 40 & 0.001104 & 0.001094 & 0.001084 & 0.001074 & 0.001065 \\
\hline 45 & 0.000872 & 0.000864 & 0.000857 & 0.000849 & 0.000841 \\
\hline 50 & 0.000706 & 0.0007 & 0.000694 & 0.000687 & 0.000681 \\
\hline
\end{tabular}

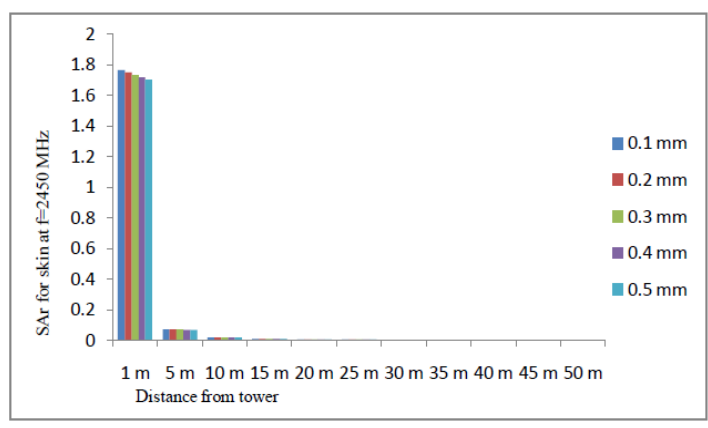

Fig4. The variation of $S A R$ in $W / K g$ for skin at frequency $2450 \mathrm{MHz}$ 
American Research Journal of Physics, Volume 1, Issue 2, 2016

ISSN 2380-5714

Table5. SAR inside the blood due to the electromagnetic wave (800 MHz) of mobile phone tower at depths $0.1 \mathrm{~mm}$ to $0.5 \mathrm{~mm}$ inside the body from $1 \mathrm{~m}$ to $50 \mathrm{~m}$ from the mobile phone tower.

\begin{tabular}{|c|c|c|c|c|c|}
\hline \multirow{2}{*}{ Distance from tower in (m) } & \multicolumn{5}{|c|}{ SAR for blood tissue at f=800 MHz } \\
\cline { 2 - 6 } & $\mathbf{0 . 1}$ & $\mathbf{0 . 2}$ & $\mathbf{0 . 3}$ & $\mathbf{0 . 4}$ & $\mathbf{0 . 5}$ \\
\hline 1 & $\mathbf{1 . 6 7 8 8 0 6}$ & $\mathbf{1 . 6 6 7 2 0 1}$ & $\mathbf{1 . 6 5 5 6 7 6}$ & $\mathbf{1 . 6 4 4 2 3 1}$ & $\mathbf{1 . 6 3 2 8 6 5}$ \\
\hline 5 & 0.067152 & 0.066688 & 0.066227 & 0.065769 & 0.065315 \\
\hline 10 & 0.016788 & 0.016672 & 0.016557 & 0.016442 & 0.016329 \\
\hline 15 & 0.007461 & 0.00741 & 0.007359 & 0.007308 & 0.007257 \\
\hline 20 & 0.004197 & 0.004168 & 0.004139 & 0.004111 & 0.004082 \\
\hline 25 & 0.002686 & 0.002668 & 0.002649 & 0.002631 & 0.002613 \\
\hline 30 & 0.001865 & 0.001852 & 0.00184 & 0.001827 & 0.001814 \\
\hline 35 & 0.00137 & 0.001361 & 0.001351 & 0.001342 & 0.001333 \\
\hline 40 & 0.001049 & 0.001042 & 0.001035 & 0.001028 & 0.00102 \\
\hline 45 & 0.000829 & 0.000823 & 0.000818 & 0.000812 & 0.000806 \\
\hline 50 & 0.000671 & 0.000667 & 0.000662 & 0.000658 & 0.000653 \\
\hline
\end{tabular}

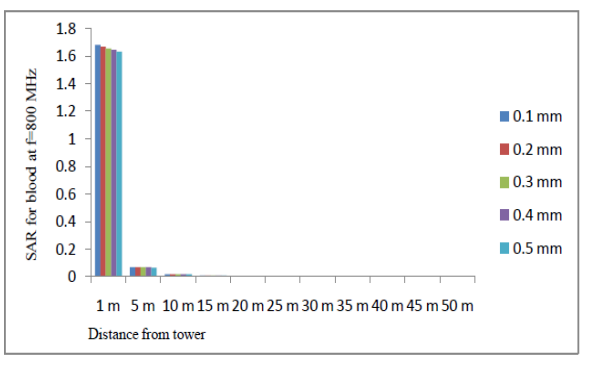

Fig5. The variation of SAR in $\mathrm{W} / \mathrm{Kg}$ for blood at frequency $800 \mathrm{MHz}$.

Table6. SAR inside the blood due to the electromagnetic wave (900 MHz) of mobile phone tower at depths $0.1 \mathrm{~mm}$ to $0.5 \mathrm{~mm}$ inside the body from $1 \mathrm{~m}$ to $50 \mathrm{~m}$ from the mobile phone tower

\begin{tabular}{|c|c|c|c|c|c|}
\hline \multirow{2}{*}{ Distance from tower in (m) } & \multicolumn{5}{|c|}{ SAR for blood tissue at f=900 MHz } \\
\cline { 2 - 6 } & $\mathbf{0 . 1}$ & $\mathbf{0 . 2}$ & $\mathbf{0 . 3}$ & $\mathbf{0 . 4}$ & $\mathbf{0 . 5}$ \\
\hline 1 & $\mathbf{1 . 7 2 5 8 5 6}$ & $\mathbf{1 . 7 1 3 4 9 7}$ & $\mathbf{1 . 7 0 1 2 2 6}$ & $\mathbf{1 . 6 8 9 0 4 3}$ & $\mathbf{1 . 6 7 6 9 4 7}$ \\
\hline 5 & 0.069034 & 0.06854 & 0.068049 & 0.067562 & 0.067078 \\
\hline 10 & 0.017259 & 0.017135 & 0.017012 & 0.01689 & 0.016769 \\
\hline 15 & 0.00767 & 0.007616 & 0.007561 & 0.007507 & 0.007453 \\
\hline 20 & 0.004315 & 0.004284 & 0.004253 & 0.004223 & 0.004192 \\
\hline 25 & 0.002761 & 0.002742 & 0.002722 & 0.002702 & 0.002683 \\
\hline 30 & 0.001918 & 0.001904 & 0.00189 & 0.001877 & 0.001863 \\
\hline 35 & 0.001409 & 0.001399 & 0.001389 & 0.001379 & 0.001369 \\
\hline 40 & 0.001079 & 0.001071 & 0.001063 & 0.001056 & 0.001048 \\
\hline 45 & 0.000852 & 0.000846 & 0.00084 & 0.000834 & 0.000828 \\
\hline 50 & 0.00069 & 0.000685 & 0.00068 & 0.000675 & 0.000671 \\
\hline
\end{tabular}

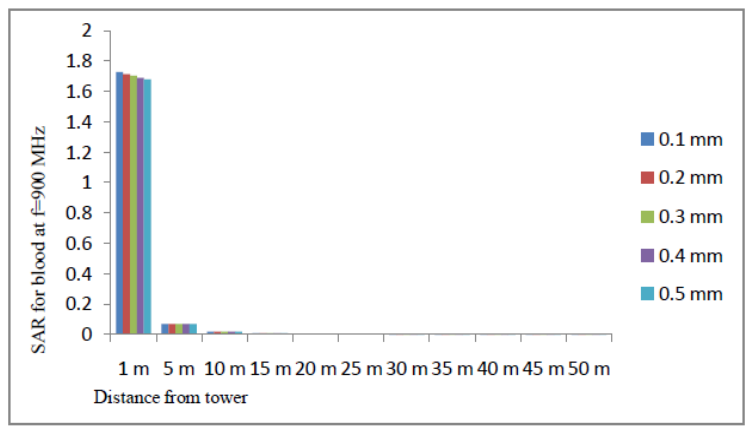

Fig6. The variation of SAR in $\mathrm{W} / \mathrm{Kg}$ for blood at frequency $900 \mathrm{MHz}$. 
American Research Journal of Physics, Volume 1, Issue 2, 2016

ISSN 2380-5714

Table7. SAR inside the blood due to the electromagnetic wave (1800 MHz) of mobile phone tower at depths $0.1 \mathrm{~mm}$ to $0.5 \mathrm{~mm}$ inside the body from $1 \mathrm{~m}$ to $50 \mathrm{~m}$ from the mobile phone tower.

\begin{tabular}{|c|c|c|c|c|c|}
\hline Distance from tower in (m) & \multicolumn{5}{|c|}{ SAR for blood tissue at f=1800 MHz } \\
\cline { 2 - 6 } & $\mathbf{0 . 1}$ & $\mathbf{0 . 2}$ & $\mathbf{0 . 3}$ & $\mathbf{0 . 4}$ & $\mathbf{0 . 5}$ \\
\hline 1 & $\mathbf{2 . 2 8 7 1 4 8}$ & $\mathbf{2 . 2 6 4 7 2 8}$ & $\mathbf{2 . 2 4 2 5 2 8}$ & $\mathbf{2 . 2 2 0 5 4 6}$ & $\mathbf{2 . 1 9 8 7 8}$ \\
\hline 5 & 0.091486 & 0.090589 & 0.089701 & 0.088822 & 0.087951 \\
\hline 10 & 0.022871 & 0.022647 & 0.022425 & 0.022205 & 0.021988 \\
\hline 15 & 0.010165 & 0.010065 & 0.009967 & 0.009869 & 0.009772 \\
\hline 20 & 0.005718 & 0.005662 & 0.005606 & 0.005551 & 0.005497 \\
\hline 25 & 0.003659 & 0.003624 & 0.003588 & 0.003553 & 0.003518 \\
\hline 30 & 0.002541 & 0.002516 & 0.002492 & 0.002467 & 0.002443 \\
\hline 35 & 0.001867 & 0.001848 & 0.00183 & 0.001812 & 0.001795 \\
\hline 40 & 0.001429 & 0.001415 & 0.001401 & 0.001388 & 0.001374 \\
\hline 45 & 0.001129 & 0.001118 & 0.001107 & 0.001097 & 0.001086 \\
\hline 50 & 0.000915 & 0.000906 & 0.000897 & 0.000888 & 0.000879 \\
\hline
\end{tabular}

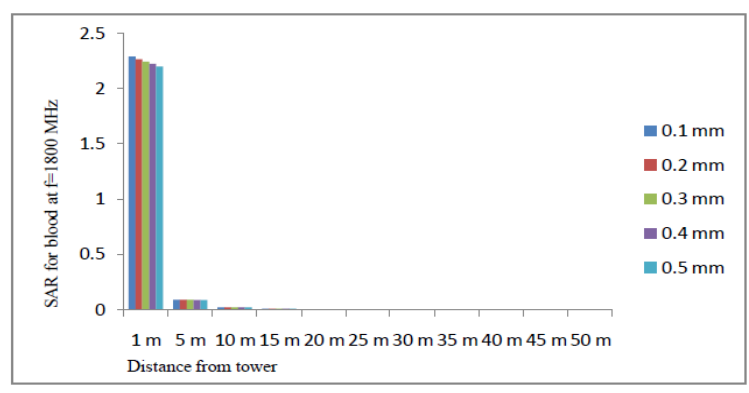

Fig7. The variation of SAR in W/Kg for blood at frequency $1800 \mathrm{MHz}$.

Table 8. SAR inside the blood due to the electromagnetic wave (2450 MHz) of mobile phone tower at depths $0.1 \mathrm{~mm}$ to $0.5 \mathrm{~mm}$ inside the body from $1 \mathrm{~m}$ to $50 \mathrm{~m}$ from the mobile phone tower.

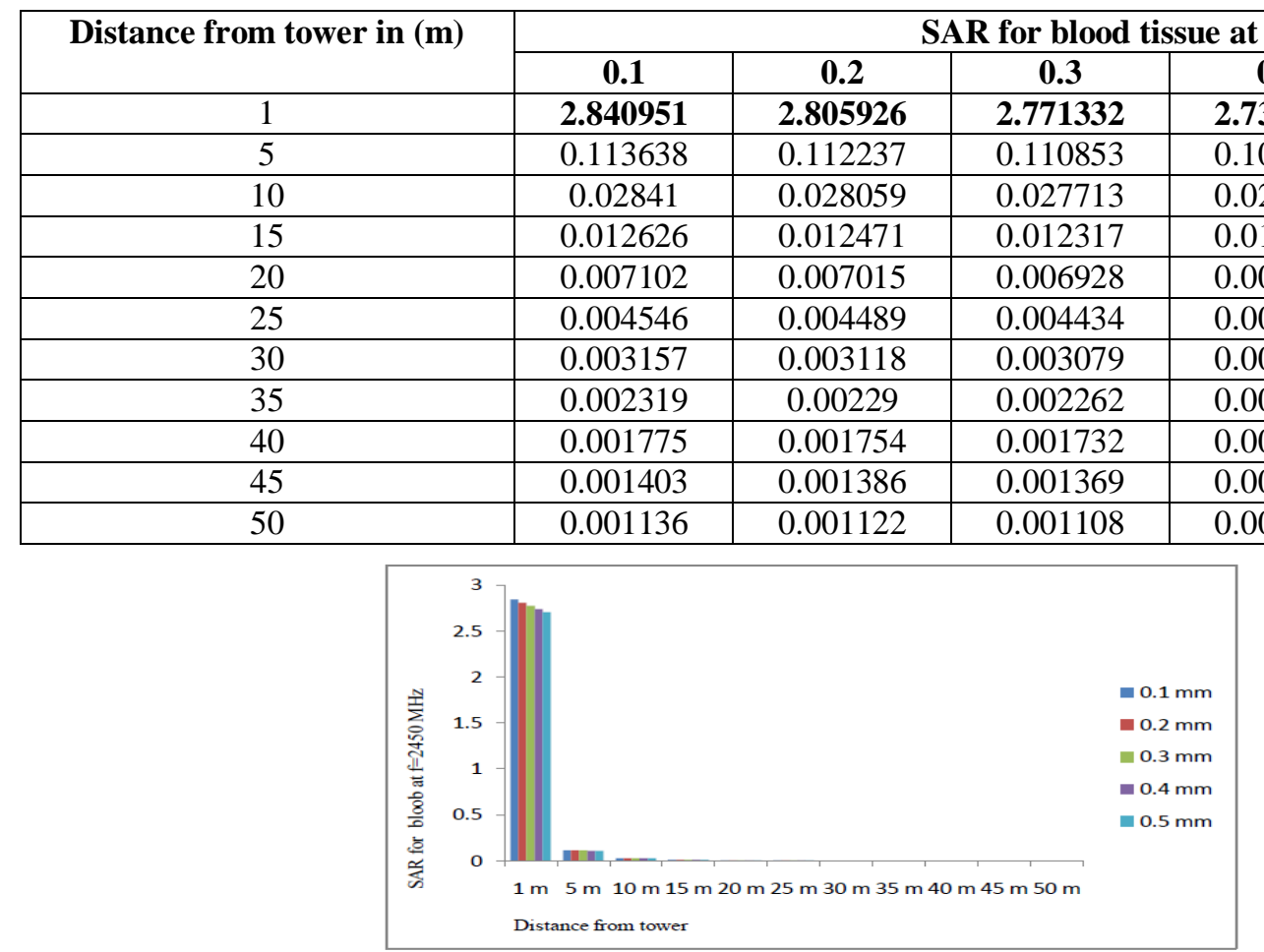

Fig8.The variation of SAR in W/Kg for blood at frequency $2450 \mathrm{MHz}$. 


\section{CONClusions}

According to some International agencies International Commission of Non-Ionizing Radiation Protection and World Health Organization, the specific absorption rate (SAR) becomes harmful after $0.4 \mathrm{~W}$ per $\mathrm{kg}$ of the body weight and for person of weight $76 \mathrm{~kg}$, the safe limit of specific absorption rate is $120 \mathrm{~W} / \mathrm{kg}$. It means that SAR may be harmful for the tissue life of the human being, if their values become greater than $120 \mathrm{~W} / \mathrm{kg}$. Bold data in tables shows harmful effect.

Table 1 represents specific absorption rate (SAR) for skin tissues due to EMW of frequency $800 \mathrm{MHz}$ This shows that the value of SAR decreases as the distance is increased. After comparing the data it is found that at $800 \mathrm{MHz}$ frequency of mobile phone tower SAR is harmful for the life of the skin tissues up to $1 \mathrm{~m}$ distance from the body till $0.5 \mathrm{~mm}$ depth.

Table 2 represents SAR for muscle tissues due to EMW of frequency $900 \mathrm{MHz}$ After comparing the data it is found that at $900 \mathrm{MHz}$ frequency of mobile phone tower SAR is harmful for the life of the skin tissues up to $1 \mathrm{~m}$ distance from the body till $0.5 \mathrm{~mm}$ depth.

Table 3 represents SAR for skin tissues due to EMW of frequency $1800 \mathrm{MHz}$ It is found that at $1800 \mathrm{MHz}$ frequency of mobile phone tower SAR is harmful for the life of the skin tissues up to $1 \mathrm{~m}$ distance from the body till $0.5 \mathrm{~mm}$ depth.

Table 4 represents SAR for skin tissues due to EMW of frequency $2450 \mathrm{MHz}$ The value of SAR decreases as the distance is increased. After comparing the calculated data it is found that at $2450 \mathrm{MHz}$ frequency of mobile phone tower SAR is harmful for the life of the skin tissues up to $1 \mathrm{~m}$ distance from the body till $0.5 \mathrm{~mm}$ depth.

Table 5 represents SAR for bone tissues due to EMW of frequency $800 \mathrm{MHz}$ From this it is found that at $800 \mathrm{MHz}$ frequency of mobile phone tower SAR is safe for the life of the blood tissues up to $1 \mathrm{~m}$ distance from the body till $0.5 \mathrm{~mm}$ depth.

Table 6 represents SAR for blood tissues due to EMW of frequency $900 \mathrm{MHz}$ This shows that at $900 \mathrm{MHz}$ frequency of mobile phone tower SAR is safe for the life of the blood tissues up to $1 \mathrm{~m}$ distance from the body till $0.5 \mathrm{~mm}$ depth.

Table 7 represents SAR for blood tissues due to EMW of frequency $1800 \mathrm{MHz}$. This shows that the value of SAR decreases as the distance is increased. After comparing the data it is found that at $1800 \mathrm{MHz}$ frequency of mobile phone tower SAR is safe for the life of the blood tissues up to $1 \mathrm{~m}$ distance from the body till $0.5 \mathrm{~mm}$ depth.

Table 8 represents SAR for blood tissues due to EMW of frequency $2450 \mathrm{MHz}$ This shows that the value of SAR decreases as the distance is increased. After comparing the data it is found that at $2450 \mathrm{MHz}$ frequency of mobile phone tower, SAR is safe for the life of the blood tissues up to $1 \mathrm{~m}$ distance from the body till $0.5 \mathrm{~mm}$ depth.

\section{REFERENCES}

[1] P. Gajsek, M. Ziriax M.,W.D. Hurt , J.T. Walters and P.A. Mason, "Predicted SAR in Sprague dawley rat as a function of permittivity values," Bioelectromagnetics, vol. 22, no.10, pp. 384-400, 2001.

[2] P. Gajsek, W.D. Hurt, M.S. Ziriax and P.A. Mason, " Parametric dependence of SAR on permittivity values in a man model," IEEE Transactions on biomedical engineering, vol. 48, no.10, pp. 1169-1177, 2001.

[3] ICNIRP www. icnirp. Org / documents / emfgdl.pdf,(2010).

[4] C.L. James, "IEEE Antenas and Propagation Magazine," vol. 45, no.3, 2003.

[5] J.J. Cleveland ,D.M. Sylvar, J.L.Ulcek, "Evaluating Compliance with FCC Guidelines for Human Exposure to Radiofrequency Electromagnetic Fields”, OET BULLETIN, 65, 1997.

[6] A.Hoyto, J. Juutilainen, J. Naarala., “ Ornithine decarboxylase activity is affected in primary astrocytes but not in secondary cell lines exposed to $872 \mathrm{MHz}$ RF radiation,” Int Journaal of Radiat Biol, vol. 83, pp. 367-374, 2007.

[7] Roosli, "Radiofrequency electromagnetic field exposure and non-specific symptoms of ill health," A systematic review, Environmental Research, 2008. 